Ankara Üniversitesi

SBF Dergisi,

Cilt 75, No.2, 2020, s. $589-606$

Araştırma Makalesi

DOI: $10.33630 /$ ausbf. 571625

\title{
AVRUPA BIRLIĞi VE KRizLER: TARIHi VE GÜNCEL KRizLER ÜZERINE BIR DEĞERLENDIRME *
}

\author{
Dr. Öğr. Üyesi Seven Erdoğan \\ Recep Tayyip Erdoğan Üniversitesi \\ İktisadi ve İdari Bilimler Fakültesi \\ ORCID: 0000-0001-9991-2074
}

\section{Öz}

1950'li yılların sonunda Avrupa Topluluğu'nun kurulmasıyla Batı Avrupa'da ortaya çıkan bütünleşme hareketi, zaman içinde gelişerek Avrupa Birliği'ne dönüşmüştür Avrupa Birliği altmış yılı aşan bütünleşme tarihinde çok sayıda krizle mücadele etmek zorunda kalmışstır. Krizler Avrupa bütünleşmesinin gelişim sürecini derinden etkilemiştir. Ancak günümüzde altmış yılı geride bırakan bir bütünleşme örneği olan Avrupa Birliği'nde bile krizlerle mücadele etmek halen oldukça büyük bir meydan okumadır. Avrupa Birliği hakkında son dönemde yapılan akademik çalışmaların yoğunlaştığ konulardan biri de Birliğin 2000'li yıllar sonrasında birbiri ardına ya da eş zamanlı olarak yaşadığı krizler olmuştur. İngiltere'nin üyelikten ayrılma kararı, mülteci krizi ve Avro krizi gibi son dönemde yaşanan ve kesin bir şekilde çözülemeyen krizler halen Avrupa Birliği gündemini çokça meşgul etmektedir. Bu çalışmanın amacı Avrupa bütünleşmesi açısından meydan okuma niteliğindeki krizlerin, bütünleşme üzerindeki etkilerini tarihsel ve güncel krizleri birlikte dikkate alarak ele almaktır. Bu kapsamda 1960'lı yıllarda yaşanan ilk krizlerinden başlanarak bütünleşme tarihinde yaşanan krizler kronolojik olarak ele alınarak krizler sonrasında Topluluk ya da Birlik sisteminde meydana gelen değişimler üzerinde durulmuştur. Çalışmanın sonunda Avrupa Birliği tarihinde geçmiş dönemlerde yaşanan krizler ve sonuçlarından hareketle mevcut krizlerin de bütünleşme üzerinde ortaya çıkarabileceği olası değişimler hakkında çıkarımda bulunulmaya çalışılmıştır.

Anahtar Sözcükler: Avrupa Birliği, Kriz, Bütünleşme, Krizle Mücadele, Avrupa Birliği’nin Geleceği

European Union and Crises: A Review on The Historical and Current Crises

\begin{abstract}
The integration attempt, which emerged in the Western Europe in the late 1950s with the establishment of the European Community, transformed into the European Union in time. The European Union has faced many crises in the historical process. These crises have affected the development path of the European integration tremendously. However, fighting against the crises has still been a major challenge for the European Union even after the passing sixty years. One of the issues taking academic attention in recent years is the European Union's consecutive and concurrent crises since the beginning of new millennium. The recent crises such as the UK's decision to exit from the EU, refugee crisis, and Euro crisis have not been solved totally and still have had an enormous place in the Union's agenda. This study aims to examine the effect of the challenging crises on the European integration process by considering the historical and current crises together. In this scope, the crises affecting the European integration since 1960s have been elaborated in a chronological order by considering their effects on the Community or Union. The study aims to provide an insight about the potential changes in the European Union system in the aftermath of the current crises by taking into account the experiences and implications of the previous crises.
\end{abstract}

Keywords: European Union, Crisis, Integration, Fighting with Crisis, Future of the European Union

* Makale geliş tarihi: 27.11.2017

Makale kabul tarihi: 31.08.2018

Erken görünüm tarihi: 30.05.2019 


\section{Avrupa Birliği ve Krizler: Tarihi ve Güncel Krizler Üzerine Bir Değerlendirme*}

\section{Giriş}

Krizler, bir siyasi sistemde işlerin normal işleyiş̧ini bozarak düzensizlikler yaşanmasına neden olan gelişmelerdir. Krizler sistemin işleyişini etkilemelerinin yanı sıra sistemin üzerine inşa edildiği değerleri de etkilemektedir. Gerekli tedbirlerin alınmaması halinde bazı krizler, siyasi sistemin yaşamsal bütünlüğünü tehdit eden durumlar ortaya çıkarabilmektedir (Saurugger, 2016: 72). Bir sistemin kendisinden beklenen sonuçları ortaya çıkaramaması da sıklıkla o sistemde kriz koşullarının geçerli olması olarak yorumlanmaktadır. $\mathrm{Bu}$ çıkarımdan hareketle Avrupa Birliği (AB) gibi bir siyasi sistemde, bütünleşmenin varlık sebebi olarak görülen ve tüm üye devletler tarafından benimsenen ortak hedeflere hizmet eden ortak bir fayda üretilememesi kriz olarak görülmektedir (Koeck, 2017: 27). Krizler, erken dönemlerden itibaren Avrupa bütünleşmesinde inkâr edilemez bir role sahip olmuştur. Zaten AB'nin kurucu babası olarak anılan Jean Monnet de hatıralarında "Krizlerden yaratılmış olan bir Avrupa'nın bu krizler için geliştirilecek çözümlerden meydana geleceğini ifade etmiştir.” (Monnet, 1978: 417).

Krizler, çoğunluğu Batı Avrupa'da yer alan Almanya, Fransa, İtalya, Hollanda, Belçika ve Lüksemburg'tan teşkil eden altı ülkenin, Avrupa'da bütünleşmeyi sağlamak üzere ilk adımları atmalarında etkili olmuştur. İkinci Dünya Savaşı sonrasında Sovyet tehdidinin yükselişe geçtiği bir ortamda bu altı ülke, kömür ve çelik alanındaki yetkilerini Avrupa Kömür ve Çelik Topluluğu adı verilen bir ulusüstü örgüte devretmişlerdir. Bu örgüt çatısı altında yaptıkları işbirliğinin ortaya çıkardığı olumlu sonuçlar, altıları aralarındaki ilişkiyi daha ileri noktalara taşımaya motive etmiştir. İşte bu ortamda, savunma ve siyasi birlik oluşturma fikri gündeme gelmiştir. Bu iki birlik, fikri ortaya atan Fransa'nın parlamentosunda onaylanmayarak hayata geçirilemeyince, 1950'li yılların ortalarında Avrupa'da kısa süreli bir belirsizlik ortamı yaşanmıştır (McCormick, 2014: 100). Bu belirsizlik ortamı, 1957 yılında imzalanan Roma Antlaşmaları ile

* Bu çalışma 11-13 Ekim 2017 tarihlerinde Bosna Hersek, Saraybosna'da düzenlenen 3rd International Conference on Education, Culture and Identity (ICECI 2017) isimli konferansta sözlü olarak sunulmuştur. 
günümüz AB'sinin öncülü konumundaki Avrupa Ekonomik Topluluğu ve Avrupa Atom Enerjisi Topluluğu'nun kurulmasıyla aşılmıştır. Bu iki topluluk kısaca Avrupa Topluluğu ya da Toplulukları (AT) olarak anılmıştır.

1950'li yıllarda kurulmasının ardından Avrupa'daki bütünleşme deneyimi çok sayıda krizle mücadele etmek zorunda kalmıştır. Bu süreçte üye devletlerin, ağırlıklı olarak Topluluk ya da Birlik kurumlarıyla işbirliği halinde davranarak geçmişteki krizleri aşmak üzere gerekli çabayı gösterdikleri gözlenmiştir. Ancak kuruluşunun ardından altmış yılı aşan bir süreyi geride bırakan ve zaman içinde beliren yeni koşullara ayak uydurma konusunda inkâr edilemez bir başarı gösteren $\mathrm{AB}$ açısından bile, son dönemlerde birbiri ardına ya da eş zamanlı olarak ortaya çıkan krizlerle mücadele etmek halen oldukça büyük bir meydan okumadır. Dolayısıyla $\mathrm{AB}$ hakkında yapılan güncel akademik çalışmaların yoğunlaştığı konuların en başında Birliğin içinde bulunduğu krizler gelmektedir.

$\mathrm{Bu}$ çalışmada $\mathrm{AB}$ bütünleşmesi açısından bir meydan okuma niteliğindeki krizlerin bütünleşme üzerindeki etkileri tarihsel ve güncel krizler birlikte ele alınarak değerlendirilmektir. Bu kapsamda 1960'lı yıllarda yaşanan AB'nin ilk krizlerinden başlanarak $\mathrm{AB}$ bütünleşme tarihinde yaşanan krizler kronolojik olarak ele alınmakta ve bu yolla krizlerin Topluluk ya da Birlik sisteminde meydana getirdiği değişimler üzerinde durulmaktadır. Çalışmanın sonunda Topluluk ya da Birlik tarihinde geçmiş dönemlerde yaşanan krizlerin bütünleşme üzerindeki etkilerinden hareketle, güncel krizlerin $\mathrm{AB}$ sisteminde ortaya çıkarabileceği olası etkilere dair çıkarımlarda bulunulması hedeflenmektedir.

\section{Avrupa Bütünleşmesinin Geçmiş Dönemde Yaşadığı Krizler}

\subsection{Avrupa Bütünleşmesinin İlk Krizleri: 1960’ı Yıllar}

AT, büyük çaplı ilk krizi ile 1965 yılında yüzleşmek zorunda kalmıştır. Bu krizin odak noktasında Fransa Devlet Başkanı General De Gaulle yer almıştır. Krizin ortaya çıkmasında kendi ülkesinin çıkarlarını her şeyin üzerinde gören bir devlet adamı olan De Gaulle'ün, AT'de kararların her durumda üye devletlerin oybirliği ile alınmasını istemesi ve AT'nin kendi bütçesine sahip olmasına büyük bir direnç göstermesi etkili olmuştur. Fransa kendisi tarafından istenmeyen bu iki değişikliğin, AT sisteminde işlerlik kazanmasını önlemek üzere kendi temsilcisini AT karar alma organından çekmiştir. Tüm üye devletlerin oybirliği ile karar alınan Toplulukta, bu durum yeni karar alınmasına engel teşkil etmiştir. Fransa'nın temsilcisinin koltuğu yapılan toplantılarda boş kaldığı için bu kriz, Boş Sandalye Krizi olarak da anılmıştır. Kriz sırasında Başkan De Gaulle'ün karşısında AB'nin geleceğini ekonomik işbirliğinin ötesinde konumlandıran ve federal bir bütünleşmeden yana olan Avrupa Komisyonu Başkanı Walter 
Hallstein yer almış ve Topluluğa dair farklı vizyonlara sahip bu ikili arasında şiddetli tartışmalar yaşanmıştır (Dinan, 2014: 6, 12).

AT’nin 1960'lı yıllarda yaşanan ikinci krizinin başrolünde de Fransa Devlet Başkanı General De Gaulle yer almıştır. 1950’li yıllarda Batı Avrupa'daki bütünleşme hareketinin serbest ticaretin ötesine geçmemesi konusunda 1srar eden ve bu önerisini hayata geçirmek üzere Avrupa Serbest Ticaret Alanını kuran İngiltere, AT’nin başarısı karşısında 1960'lı yıllarda fikrini değiştirmiş ve Topluluk üyesi haline gelmek üzere başvuruda bulunmuştur. İngiltere'nin fikrini değiştirmesinde Süveyş Kanalı Krizi sonrasında artık bağımsız hareket edebilen büyük bir güç olmadığını kabullenmesi ve sömürgelerini kaybetmeye başlamasının ardından ekonomik ve güvenlik çıkarları açısından Avrupa'ya bel bağlaması oldukça etkili olmuştur (McCormick, 2014: 101). Ayrıca İngiltere AT üyesi haline gelerek içeriden, Topluluğun daha güçlü bir bütünleşme olmasına engel olmayı da hedeflemiştir. (De Grauwe, 2016: 251). İngiltere'nin AT üyeliği 1960'larda Fransa tarafindan iki kere engellenmiştir. De Gaulle bu yolla, İkinci Dünya Savaşı sırasında Fransa Nazilerin işgali altındayken ve kendisi sürgünde ülkesinin kurtuluşu için çaba sarf ederken maruz kaldığı muamelenin intikamını almaya çalışmıştır (Armaoğlu, 2016: 557). Ayrıca Fransa'nın İngiltere'ye yönelik olumsuz tutumunda İngiltere gibi güçlü bir devletin AT üyesi haline gelmesinin Fransa'nın Topluluk içindeki çıkarlarını, özellikle ortak tarım politikası alanındakileri, olumsuz etkileyeceği düşüncesi de etkili olmuştur. Bunun yanı sıra ABD'nin Avrupa üzerindeki tahakkümünden de rahatsız olan De Gaulle, İngiltere'nin AT içinde ABD'nin truva atı gibi hareket edeceğine dair fikrini de açıkça dile getirmiştir (Ludlow, 2013: 16). 1960'lar Avrupa'nın Küba Füze Krizi sırasında müttefiklerine danışmadan hareket eden ve müttefiklerinin güvenliklerini yeterince önemsemeyen ABD'ye karşı ilk güvensizliğin ortaya çıktığı yıllar olduğundan, De Gaulle bu yolla diğer AT üyesi ülkeleri kolaylıkla etkileyebilmiştir (Joffe, 1981: 837). Diğer Topluluk üyesi ülkeler Fransa'nın tepkisini çekmemek adına İngiltere'nin AT üyesi olması noktasında direnç göstermemişlerdir. Dolayısıyla İngiltere ancak De Gaulle'ün Fransa'da iktidarını kaybetmesinin ardından 1973 yılında Topluluk üyesi haline gelebilmiştir. İngiltere üyelik sürecinde yaşanan bu rencide edici durumu ve 1973 y1lında gerçekleşen üyeliğinin, Fransa'da halk oylamasına sunulmasını hiçbir zaman unutmamıştır. İngiltere'nin üyeliğinin hemen ardından ülkede iktidara gelen AT şüphecilerinin ilk işlerinden biri, 1975 yılında ülkenin AT üyeliğine ilişkin ilk referandumu düzenlemek olmuştur.

\subsection{Tüm Dünya ve Topluluk Krizde: 1970’li Yıllar}

1970'lerde AT'yi en çok etkileyen krizlerin başında aynı zamanda küresel ölçekli bir kriz olma özelliği de taşıyan petrol krizi gelmiştir. Bu dönemde petrol 
üreten ülkeler petrol satarak elde ettikleri kazançları yükseltmek üzere kartelleşme çabası içine girmiş ve Petrol İhraç Eden Ülkeler Örgütü (OPEC) ortaya çıkmıştır. Buna ek olarak petrol üreten Arap ülkeleri, İsrail'le aralarındaki mücadelede İsrail'den taraf olan Batılı ülkeleri cezalandırmak üzere petrolü koz olarak kullanmaya başlamıştır. İkinci Dünya Savaşı sonrasında 1950 ve 1960’lı yıllarda hızla büyüyen, ancak enerji kaynakları konusunda dışa bağımlı olan Avrupa ekonomilerinin büyüme hızları, artan enerji maliyetlerinden olumsuz etkilenmiştir. Bununla birlikte Topluluk üyesi ülke ekonomileri dünya enerji piyasalarında ortaya çıkan bu yeni duruma hızla uyum sağlamış ve ihraç edilen ürünler için enerji maliyetlerini dikkate alan yeni bir fiyat düzeyine geçilmiştir (Issawi, 1978-79: 16).

1970'lerde Topluluk içinde büyük bir krize neden olmasa da şok yaratan bir diğer gelişme ise 1973 y1lında İngiltere, Danimarka ve İrlanda ile birlikte AT üyesi haline gelmek isteyen Norveç'te, halkın üyelik müzakerelerinin tamamlanmasının ardından düzenlenen referandumla AT üyeliğini reddetmesi olmuştur. Norveç halkı sahip oldukları zengin balık ve petrol kaynaklarını AT üyesi ülkelerle paylaşmak ve bu kaynaklar üzerindeki kontrolünü kaybetmek istememiştir. Norveç gibi müreffeh bir ülkeyi kendi üyesi haline gelmeye ikna edememesi AT açısından esasında bir başarısızlıktır. 1995 yılında Norveç halkının bir kez daha referandumla $\mathrm{AB}$ üyesi olmayı reddetmesi zaman içinde Birliğe dair algıların bu ülkede değişmediğini göstermiştir (Kux ve Sverdrup, 2000: 243-44).

\subsection{Yeni Üye Üıkeler Kaynaklı Krizler: 1980'li Yıllar}

Daha önce ifade edildiği üzere İngiltere'nin AT’ye üye olmasının nedenlerinden biri de, dışarıdan müdahale ederek engel olamadığ 1 Avrupa bütünleşmesinin ileri noktalara taşınmasına, üye haline gelerek içeriden engel olma isteğidir. İngiltere üye olmasının ardından Topluluğun kendi önceliklerine uygun bir dönüşüm geçirmesini sağlamaya çabalamıştır. Diğer Topluluk üyesi ülkelerin İngiltere ile benzer bir görüşe sahip olmamaları, üyeliğinin ardından İngiltere, sürekli olarak sorun çıkaran bir AT üyesi haline gelmiştir. İngiltere Topluluk üyesi olmasının ardından AT bütçesine yaptığı katkıyı sorun haline getirmiştir. Bütçeye yaptı̆̆ katkıya kıyasla AT bütçesinden daha az pay almasını ve Topluluk bütçesinin politika alanları itibariyle dağılımını, özellikle de ortak tarım politikasına ayrılan payı, sorun haline getirmiştir. İngiltere'nin bütçesel sıkıntıları 1980'li yıllarda tavan yapmıştır. 1980'lerde İngiltere Başbakanı olan Margaret Thatcher ulusal düzeyde demir leydi lakabını kazanmasını sağlayan sivri dilli tutumunu AT içinde de devam ettirerek, toplantılarda "paramızı geri verin" demekten çekinmemiştir. İngiltere'nin bütçe sorunu bölgesel uyum fonunun oluşturulması ve ülkenin Topluluk bütçesine yaptığı katkıda indirime 
gidilmesiyle 1984 yılında aşılmıştır (Begg, 1999: 3). Bütçe konusunun yanı sıra İngiltere, 1990'larla birlikte ortak pazara dönüşmeye yönelik hazırlıkların yapıldığı 1980'lerde, sürecin fikirsel liderliğini yürüten Avrupa Komisyonu Başkanı Jacques Delors'u en fazla uğraştıran Topluluk üyesi olmuştur (McCormick, 2014: 454).

1981 yılında AT üyesi haline gelen Yunanistan da üye olmasının ardından İngiltere gibi Topluluk içinde huzursuzluklara neden olan bir üye ülke görünümünde olmuştur. Yunanistan'da üyelik sonrası dönemde yönetime gelen AT karşıtı iktidarlar, seçim döneminde verdikleri vaatlere karşın, ülkenin içinde bulunduğu ekonomik koşullar nedeniyle üyelikten vazgeçmeye cesaret edememiştir. Ancak bir takım itirazlar yoluyla AT bütçesinden ülkelerinin daha fazla pay elde etmesi için çaba sarf etmişlerdir (Dinan, 2008: 231). Bunun yanı sıra, Yunanistan'ın üyeliğinin ardından AT'nin Türkiye'ye ilişkin tutumunda da radikal bir değişim yaşanmıştır. 1980'ler sonrasında Topluluğun Türkiye'ye karş1 tutumunda Yunanistan ile Türkiye arasındaki ilişkilerde yaşanan gerginliklerin ve özellikle de Kıbrıs Sorunu faktörünün etkisi sürekli olarak hissedilmiştir (Öniş, 2001: 36).

\subsection{Soğuk Savaşın Bitmesinin Ardından Gelen Krizler: 1990'lı Yıllar}

1990'larda Soğuk Savaşın bitmesiyle uluslararası politikada radikal bir dönüşüm yaşanmıştır. $\mathrm{Bu}$ dönüşüme cevaben Maastricht Antlaşması ile topluluktan birlik haline gelen Avrupa bütünleşmesi, büyük bir değişim geçirmiştir. 1990 öncesi dönemde daha çok ekonomik alanlarda bütünleşerek yollarına devam eden AB üyesi ülkeler, 1990'larla birlikte dünya sisteminde meydana gelen radikal değişimle, kaçınılmaz bir şekilde savunma ve dış politika konularında faaliyet göstermek zorunda kalmıştır. Maastricht Antlaşması ile Sovyet tehdidinin olmadığı bir uluslararası siyasi ortamda, ABD'nin Avrupalıların güvenliğini sağlamak noktasında daha az istekli olacağı tahmininden hareketle, Avrupa bütünleşmesine güvenlik ve dış politika boyutu eklenmiştir. Üye devletlerden $\mathrm{AB}$ düzeyine egemenlik açısından hassas konularda yetki devrinde bulunulması neticesinde Maastricht Antlaşması'nın bazı ülkelerde onaylanması sancılı olmuştur. Maastricht Antlaşması sonrasında imzalanan her yeni antlaşmanın onay sürecinde benzer sorun ve sıkıntılar yaşanmıştır. Antlaşmaların tüm üye devletlerce onaylanmasını sağlamak üzere, bazı üye ülkelere bir takım tavizler verilmiş ya da bazı üye ülkelere bazı politika alanlarına katılmama hakkı tanınmıştır. Bazı üye ülkelere sağlanan bu tür ayrıcalık ve istisnalar neticesinde, $A B$ her üye devletin aynı oranda bütünleşmediği ve bu nedenle de hukuken olmasa da fiiliyatta farklı üyelik şekillerinin söz konusu olduğu bir bütünleşme haline gelmiştir. 
1990'larda yaşanan bir diğer kriz ise Avrupa'nın yanı başındaki Yugoslavya'nın dağılmasının ardından bu ülkedeki farklı etnik gruplar arasında çıkan anlaşmazlıklar karşısında, AB'nin etkin bir aktör olarak hareket edememiş olmasıdır. Avrupa, yanı başındaki Bosna ve Kosova'da yaşanan vahşete seyirci kalmakla suçlanmıştır. ABD'nin Avrupa'daki güvenliği sağlamak konusunda isteksiz hale geldiği ve bu konuda $\mathrm{AB}$ 'nin daha gayretli olması gerektiğini vurguladığ 1 bir dönemde, $\mathrm{AB}$ üyesi ülkelerin gereken zamanda gerekli müdahaleyi yapamamaları, en nihayetinde NATO müdahalesini gerekli kılmıştır. $\mathrm{Bu}$ durum $\mathrm{AB}$ üyesi ülkelerin Avrupa'da güvenliği sağlamak noktasındaki zayıflıklarını açık bir şekilde ortaya koymuştur. Bu dönemde dış politika ve savunma konularındaki zaaflarından dolayı AB'nin ekonomik olarak bir dev olmakla birlikte, siyasi olarak cüce olduğu tespitinde bulunulmuştur (Dinan, 2008: 315-16).

AB, 1990'lardan itibaren demokrasi açı̆̆ı, meşruiyet krizi, yaşlanan nüfus, sosyal dışlanma, terörizm ve düşük büyüme oranları ve rekabet seviyesi gibi zorlayıcı faktörlerle mücadele eder hale gelmiştir. Hâlihazırda kesin bir çözüm bulunamayan bu sorunlar, $\mathrm{AB}$ gündemini halen meşgul etmeye devam etmektedir. Yaşlanan nüfus haricindeki problemlerin, AB'ye özellikle siyasi alanda devredilen yetkiler arttıkça ve AB'nin refah yaratma hızı düşük seyrettiği sürece devam edeceği ileri sürülebilir. $\mathrm{Bu}$ da $\mathrm{AB}$ 'nin ekonomik başarı dışında yeni meşruiyet kaynakları yaratmaya ciddi şekilde ihtiyaç duyduğunu göstermektedir (Özdemir, 2012: 388, 390).

\section{Avrupa Birliği’nde Yakın Dönemde Bitmeyen Kriz Ortamı: 2000'li Yıllar}

\subsection{Irak Müdahalesi ve Avrupa Birliği}

Soğuk Savaşın bitmesiyle birlikte kendi güvenliklerini sağlamak adına daha fazla çaba sarf etmeleri gerektiğinin farkına varan $\mathrm{AB}$ üyesi ülkeler, aralarındaki işbirliğini dış politika ve güvenlik alanlarını da kapsayacak şekilde genişletmişlerdir. Ancak, AB düzeyinde izlenen ortak politikalar hiçbir zaman üye devletlerin kendi ulusal çıarlarına uygun olarak yürüttükleri ulusal politikalar kadar etkili olamamıştır (Smith, 2003: 3). 2003 yılında ABD'nin Irak'a yaptığı müdahale öncesinde ve sırasında yaşananlar AB'nin dış politika alanındaki zaaflarını ve çok başl1lığını gözler önüne sermiştir. Eski Avrupa olarak adlandırılan Almanya ve Fransa, Birleşmiş Milletler kararı olmaksızın uluslararası toplumun rızasına aykırı bir şekilde yapılacak olan bir müdahalenin uluslararası hukuka aykırı olduğunu şiddetle savunurken; İngiltere, İspanya, Hollanda gibi $\mathrm{AB}$ üyesi ülkeler, bu müdahale sırasında $\mathrm{ABD}$ 'yi açıkça desteklemiştir. Bu iki kampa ek olarak Finlandiya, İsveç, Portekiz ve İrlanda'dan 
oluşan bir de tarafsız üyeler grubu ortaya çıkmıştır. Yani AB üyesi ülkeler bu konuda bir uzlaşı içinde hareket edebilmeyi başaramamıştır. Bununla birlikte ABD müdahalesini resmi olarak destekleyen ülkelerde bile vatandaşların bu müdahaleyi kınayan protestolar gerçekleştirmiş oldukları da ayrıca belirtilmelidir (McCormick, 2014: 323-24).

\subsection{Anayasal Antlaşma'nın Rafa Kaldırılması}

AB, 1990 sonrasında sıklıkla revize edilen antlaşmalarla ulusal kimlik ve egemenlik konusunda hassas politika alanlarına yayılınca, üye devletlerde ekonomi, refah ve güvenlik gibi konuları derinden etkiler hale gelmiştir. $\mathrm{Bu}$ yüzden $\mathrm{AB}$ vatandaşlarının hayatlarında yolunda gitmeyen şeyler için $\mathrm{AB}$ 'yi suçlama eğilimlerinde artış yaşanmıştır. Vatandaşlar hoşnutsuzluklarını AB şüphecisi partilere oy vererek ya da yeni $\mathrm{AB}$ antlaşmalarının onaylanmasına engel olarak göstermiştir. Geleneksel olarak $\mathrm{AB}$ destekçisi olan Güney Avrupa ülkelerinin halkları bile, İngiltere ve Danimarka gibi geleneksel olarak AB karşıtı ülke vatandaşlarına yakın düzeyde bir $\mathrm{AB}$ şüpheciliğine sahip hale gelmiştir (Schimmelfennig, 2014: 322).

$\mathrm{AB}$ Antlaşmalarının üye devletlerce geçerli olan hukuki usullere göre onaylanması sırasında yaşanan en büyük kriz, Anayasal Antlaşma'nın 2004 yllında AB'nin iki kurucu üyesi Hollanda ve Fransa'da referandumla reddedilmesi ile birlikte yaşanmıştır. Anayasal Antlaşma ile ortaya çıkması muhtemel neo-liberal ekonomik modele yönelik kaygılar, anlaşmanın ulusal egemenliğe vuracağı büyük darbe ile antlaşmaya destek veren hükümetten duyulan rahatsılılı Fransa'da referandum sürecinde halkın tercihinin hayır olmasında etkili olmuştur. Fransa'da ret sonucunun alınmasının ardından referanduma giden Hollanda'da; antlaşmanın içeriğine dair bilgi eksikliği, hükümetten duyulan memnuniyetsizlik, Avrupa bütünleşmesinin elit tekelinde halkın iradesi dışında ilerlemesi, başta Türkiye olmak üzere gelecekte AB üyesi haline gelecek ülkelerden yaşanacak kitlesel göçler gibi faktörler Hollanda halkının nihai kararında belirleyici olmuş ve Fransa'nın ardından bir hayır sonucu da bu ülkede alınmıştır (McCormick, 2015: 145).

Başka üye ülkelerde de antlaşmanın reddedilme potansiyelinin olması neticesinde, $\mathrm{AB}$ üyesi ülkeler Anayasal Antlaşma'dan vazgeçmek zorunda kalmıştır. Antlaşmanın onaylanmaması ile baş gösteren siyasi kriz ortamı, 2007 yılında Lizbon Antlaşmasının imzalanması sayesinde aşılabilmiştir. Lizbon Antlaşması'nın imzalanmasının ardından geçen on yılı aşan süreye ve bütünleşmenin ortaya çıkan yeni ihtiyaçlarına karşın, Birlik üyesi ülkelerin antlaşma revizyonuna gitmekten ciddi şekilde çekinmeleri onay krizinin etkilerinin halen devam ettiğinin bir kanıtı niteliğindedir. 


\subsection{Avrupa Birliği’nin Avro Krizi ile İmtihanı}

2007 yılında imzalanan Lizbon Antlaşması ile siyasi kriz ortamının geride kaldığını düşünerek geleceğe umutla bakan AB, 2007 yılında ABD'de başlayan ekonomik krizin 2008 yılında Avro alanında hissedilmesiyle bu kez de tarihindeki en büyük ekonomik krizle başa çıkmak zorunda kalmıştır (Bauer ve Becker, 2014: 213). Avro krizi birden fazla krizi bünyesinde barındıran ve bu özelliğinden dolayı da farklı isimlerle anılan bir krizdir. Avro krizinin yanı sıra bu kriz; borç krizi, bankacılık krizi, büyüme ve rekabet edebilirlik krizi gibi isimlerle de ifade edilmektedir (Lawrence, 2013: 194). Her ne kadar ekonomik bir kriz olsa da Avro krizi, uzunca bir süre $\mathrm{AB}$ gündemini meşgul ederek Avrupa bütünleşmesinin tüm boyutlarını etkilemiştir.

Avro krizi ile mücadelede $\mathrm{AB}$ üyesi ülkeler, ilk etapta dayanışma içinde davranarak ekonomik bir darboğazın içinde olan Yunanistan, İrlanda ve Portekiz gibi ülkelere yardımcı olma konusunda istekli bir tutum içinde olmamıştır. Bu durum krizin daha da derinleşmesini beraberinde getirmiştir. AB üyesi ülkeler sonrasında bu eylemsizlik durumundan vazgeçerek krizi ve etkilerini ortadan kaldırmaya yönelik yeni politika ve araçlar inşa etme çabasına girmişlerdir (Lawrence, 2013: 198). Birlik üyesi ülkeler geç olsa da en nihayetinde Avro alanının $\mathrm{AB}$ bütünleşmesini ayakta tutan temellerden biri olduğunun anlayarak, Avrodan vazgeçmenin kolay olmadığı sonucuna varmışlardır (Schimmelfennig, 2014: 328). Temel olarak Avro'nun korunmasinı ve benzer krizler karşısında Avro alanının daha güçlü bir hale getirilmesini hedefleyen bu politika ve araçlar yoluyla, bir taraftan bankacılık sisteminin daha sıkı denetlenmesine yönelik Avrupa Bankacılık Otoritesi gibi yapılar oluşturulurken; diğer taraftan borçlarını ödemek konusunda zorluk yaşayan üye ülkelere gereken desteği sağlamak üzere daimi bir kurumsal yapı niteliğindeki 500 milyar Avro borç verme kapasitesine sahip Avrupa İstikrar Mekanizması oluşturulmuştur (Erdoğan ve Yazgan, 2017: 198-200). Dolayısıyla, kriz sonrasında bütün zorluklara rağmen Avro alanı yıkılmadan ayakta kalabilmiştir. Hatta Estonya ve Letonya'nın da katılımıyla iki kere genişlemiştir.

Avro krizi, AB üyesi ülkeler arasında kutuplaşmalara neden olmuştur. Krizi kolay atlatan ülkeler, borç batağındaki üye ülkelere yardım etmeyi istemezken; krizden etkilenen ülkeler ekonomik sıkıntılarına ek olarak kendilerine yardım etmek konusunda isteksiz olan $\mathrm{AB}$ üyesi ülkelerden gördükleri muamele karşısında Birlik içinde kendilerini yalnız ve dışlanmış hissetmişlerdir. Bu ortamda Yunan halkı AB'den çıkmayı bile talep eder hale gelmiş ve Yunanistan, kriz öncesi dönemle büyük bir tezat oluşturacak şekilde AB karşı1tlı̆ının en fazla olduğu üye ülkelerden biri olmuştur (Saurugger, 2016: 81). 
Avro krizi sonrasında krizden çok fazla etkilenen ve yüksek borç oranına sahip Yunanistan, İrlanda, Portekiz gibi üye ülkelerden; AB, Dünya Bankası ve Uluslararası Para Fonu üçlüsü tarafindan kurtarma paketleri yoluyla yapılan mali kaynak aktarımları karşılığında bir takım koşulları yerine getirmeleri talep edilmiştir. Bu kapsamda bu ülkeler, maaşlarda ve ücretlerde kesintiye gidilmesi, vergilerin arttırılması ile kamu harcamaları ve yatırımların azaltılması gibi bazı koşulları yerine getirmişlerdir. Alınan önlemlerle kamu gelirlerini arttırıcı tedbirler alınarak, kamu harcamalarında kesintiye gidilmiştir. Bu yolla söz konusu ülke ekonomilerinde finansal istikrarın yeniden sağlanması hedeflenmiştir. Buna karşın, alınan tedbirler kaçınılmaz olarak işsizlik oranlarında artışı da beraberinde getirmiştir. Ağır kemer sıkma politikalarının uygulandığ 1 ülkelerde halkın $\mathrm{AB}$ kurumlarına ve $\mathrm{AB}$ içindeki lider ülkelere, özellikle de Almanya'ya karşı öfkesinde ve protestolarında bir artış yaşanmıştır. $\mathrm{Bu}$ ortamda halka cazip gelmeyen politikaları uygulayan iktidarlar kadar, bu politikaların mimarı olarak görülen $\mathrm{AB}$ makamları ve liderleri de suçlanmıştır (Schimmelfennig, 2014: 322-23). Yaşanan sosyal huzursuzluk ortamında, AB üyesi ülkelerde demokratik yönetimler büyük ölçüde aşınmıştır. İktidarlar değişse bile uygulanan politikalar aynı kalmaya devam etmiştir. Bu koşullar altında Avrupa vatandaşlarının $\mathrm{AB}$ şüpheciliği artış göstererek $\mathrm{AB}$ 'ye karşı saldırgan bir tutum içinde olan siyasi partilerin oyları belirgin bir şekilde artmıştır (Tosun vd., 2014: 196, 200). AB vatandaşları açısından Birlik, ortaya çıkardığı faydalar ne kadar fazlaysa ve maliyetler de ne kadar azsa o kadar fazla meşru görülen bir siyasi oluşumdur. Avro krizi sonrasında AB'yi hedef alan olumsuz tepkilerin arkasında yer alan nedenlerden biri de AB'nin küreselleşmenin kaybedenlerinin durumunu iyileştirmek adına adımlar atmamasıdır. Birlik kendisinden beklenenin aksine, küreselleşmenin kaybedenlerinin durumlarının daha da kötüleşmesine hizmet eden ve küreselleşmenin kazananlarının daha fazla kazanmasına katkıda bulunan politikalar üreten bir tutum içinde olmuştur (De Grauwe, 2016: 249).

Geç de olsa Avro krizi ile mücadele etmek üzere gerekli önlemleri alan $\mathrm{AB}$ 'de krizin tüm etkilerinin tamamen ortadan kalktı̆̆ından söz etmek halen mümkün değildir. Bununla birlikte kriz, Avro alanının iyimser tahminler üzerine inşa edildiğini ve krizle mücadele için gerekli olan araçlardan yoksun olarak inşa edildiğini gözler önüne sermiştir. Avro krizi sonrası dönemde alınan önlemler sayesinde, Avro alanının geçmişe kıyasla daha güçlü bir yapı haline geldiğinden ve bundan sonra krizlere karşı daha dirençli olduğundan bahsetmek mümkündür. 


\subsection{Avrupa Birliği’ne Ulaşmaya Çalışan Milyonlarca Göçmen}

Avro krizinin olumsuz sonuçlarıyla mücadele eden $\mathrm{AB}$, eş zamanlı olarak 2010 sonrasında bir krizle daha mücadele etmek zorunda kalmıştır. AB'ye yakın coğrafyalarda birbiri ardında yaşanan siyasi krizler milyonlarca kişinin evlerini terk ederek sığınmacı haline gelmelerine neden olmuştur. Evlerini terk etmek zorunda kalan milyonlarca göçmen açısından bir refah ve güven alanı olarak görülen Avrupa, sığınılmak istenen en önemli liman haline gelmiştir. 2015 yılında rekor sayıda göçmenin Avrupa ülkelerine geçmesiyle AB üyesi ülkeler açısından göçmen krizi tavan noktasına ulaşmışıır. Avro krizi sırasında Avro üyesi olmanın gereklerini yerine getirememekle suçlanarak Avro krizinin tek sorumlusuymuş gibi görülen Yunanistan, bu sefer de AB'nin dış sınırlarını etkin bir şekilde koruyamamakla suçlanmıştır. Yunanistan'la birlikte suçlanan bir diğer ülke de İtalya olmuştur. Yasal olmayan yollarla AB üyesi ülkelere giren mülteciler, Schengen alanı ile iç sınırların engelleyici özelliğini kaybettiği Avrupa'da, daha kolay sığınma elde edebilecekleri ve gelişmiş sığınma rejimlerine sahip olan $\mathrm{AB}$ üyesi ülkelere ulaşmak için çaba göstermiştir.

$\mathrm{AB}$ üyesi ülkelerin sosyal, ekonomik ve siyasi gerçekleri, bu ülke vatandaşlarının göçmenlere yönelik tutumlarını derinden etkilemektedir. Homojen bir nüfusa sahip olan ve ekonomik olarak zorluklar yaşayan $\mathrm{AB}$ üyesi ülkelerin, göçmenlerin ülkelerindeki varlığına sıcak bakma ihtimalleri oldukça düşüktür. Bu tür Birlik üyesi ülkelerde, son yıllarda yabancı karşıtlığı söylemini kullanan siyasi parti ve hareketler kolaylıkla toplumsal destek elde ederek seçimlerde önemli başarılara ulaşabilmektedir. Dolayısıyla göçmen akını ile bağlantılı bir şekilde son dönemde birçok $\mathrm{AB}$ üyesi ülkede yabancı düşmanlığı gözlemlenir bir hale gelmiştir. Avrupa'nın 1950 sonrası dönemde imza attı̆̆ ekonomik mucizede, yabancıların sundukları işgücü sayesinde ne kadar önemli bir paya sahip oldukları; bazı $\mathrm{AB}$ üyesi ülkelerde unutulmuş vaziyettedir ya da görmezden gelinmektedir. Bu nedenle de Avrupa'ya ulaşmaya çalışan göçmenler çoğunlukla yük olarak görülmekte ve Avrupa'nın zenginliğinin artmasına yapabilecekleri katkılar hiçbir şekilde hesaba katılmamaktadır.

Göçmen krizi ile mücadelede alınan tedbirler daha çok ortaya çıkan göç olgusunun Avrupa'yı etkilemesine izin vermemek şeklinde olmuştur. Her ne kadar hem $\mathrm{AB}$ hem de üye devletler düzeyinde göçü ortaya çıaran nedenleri ortadan kaldırmanın asıl çözümü ortaya çıkaracağına dair bir düşünce söz konusu olsa da, her iki taraf da göçle mücadeledeki bu etkin ve zor adımı atmaktan uzak durmuşlardır (Koeck, 2017: 31). Yani göç edenlerin Avrupa' ya ulaşmasına engel olmaya çalışan Avrupa, bu kişileri vatanlarını ya da ikamet ettikleri yerleri terk etmeye zorlayan siyasi, ekonomik ve sosyal sorunları çoğunlukla görmezden gelmişlerdir. 
Avrupa'ya göçmenlerin akışını durdurmak üzere farklı tedbirlere başvuran $\mathrm{AB}$ üyesi ülkelerin bu amaca yönelik aldıkları önlemlerden biri de Kıbrıs sorunu nedeniyle uzun bir zamandır ihmal edilen bir aday ülke olan Türkiye ile yoğun bir işbirliğine girişilmesi olmuştur (Wirth, 2016: 45). Bu zamana kadar alınan ortaklaşa tedbirler sayesinde $\mathrm{AB}$ 'ye mültecilerin akışında önemli bir azalma meydana gelmiştir. Ancak Türkiye ile AB arasındaki ilişkilerde son dönemde, özellikle de Türkiye'de 15 Temmuz 2016' da Türkiye'de yaşanan başarısız darbe girişimin ardından beliren kriz ortamında, Türk vatandaşlarının $\mathrm{AB}$ üyesi ülkelere vizesiz seyahat etmesine yönelik talepleri bir türlü yerine getirilmeyen Türkiye'nin, gelecek dönemde mültecilerin Avrupa'ya geçişini engellemek konusunda $\mathrm{AB}$ üyesi ülkelerle işbirliği yapmaya ne kadar istekli olacağ 1 hâlihazırda belirsizdir.

\subsection{Ingiltere’nin Avrupa Birliği Üyeliğinden Ayrılma Kararı}

Avro krizinin etkilerinin giderek zayıflamaya başladığı ortamda, AB'nin göçmen krizine ek olarak uğraşmak durumunda kaldığg ikinci bir kriz ise İngiltere'nin kırk yılı aşan $A B$ üyeliğini bir kez daha tartışmaya başlaması ve en nihayetinde üyelikten ayrılmaya karar vermesi olmuştur. Daha önce de ifade edildiği üzere İngiltere, AB üyesi olmasının ardından sürekli olarak AB üyeliğine ilişkin şikâyetleri olan bir ülke olmuştur. İngiltere'nin egemenlik devri konusundaki hassasiyeti, $\mathrm{AB}$ bütünleşmesinin en önemli kazanımlarından ikisi olarak kabul edilen Avro ve Schengen alanlarına katılmamasını beraberinde getirerek, ülkenin diğer $\mathrm{AB}$ üyesi ülkelere kıyasla daha az bütünleşik olması sonucunu ortaya çıkarmıştır. Tüm $\mathrm{AB}$ üyesi ülkelerde son dönemde yükselişe geçen AB karşıtllğ̆ İngiltere'de önlenemez seviyelere ulaşmış ve 2015 yılındaki seçimleri partisinin kazanması halinde İngiltere'nin AB'den çıkıp çıkmamasına ilişkin bir referandum düzenleme sözünü veren Başbakan David Cameron, bu sözünü Haziran 2016'da düzenlenen referandumla yerine getirmek zorunda kalmıştır. Parti içindeki güçlü muhalefete karşın üyelik koşulları yeniden düzenlenen bir İngiltere'nin $\mathrm{AB}$ üyesi kalarak yola devam etmesinden yana olan Cameron açısından İngiliz halkının AB'den çıkma yönünde oy kullanması sürpriz bir gelişme olmuştur. Zira David Cameron, $\mathrm{AB}$ 'den İngiltere ile ilişkilerini gözden geçirmek için önemli tavizler elde ettiğine inanmaktaydı (Kroll ve Leuffen, 2016: 1311-12, 1316). AB üyesi ülkeler referandumda evet sonucunun çıkmasını sağlamak üzere, İngiltere'ye üye olarak kalmaya devam etmesi halinde geçerli olacak birtakım ayrıcalıklar vermeyi taahhüt etmişlerdi. Referandumda hayır sonucunun alınması, bu taahhütlerin bile İngiliz halkını AB üyeliğine devam etmeye ikna edemediğini göstermektedir. İngiliz halkının AB'den ayrılma tercihinde bulunması, Avrupa halklarının AB'ye ilişkin 
kanaatlerine hâkim olan olumsuzluğun bir ifadesi niteliğindedir. AB'nin 2000 sonrası dönemde yaşadığı krizler de İngiltere'nin çıkış kararında etkili olmuştur.

İngiltere'nin $\mathrm{AB}$ üyeliğinden ayrılması kapsamında Lizbon Antlaşması ile $\mathrm{AB}$ sisteminde ilk kez varlık kazanan Birlikten ayrılma mekanizması, işlerlik kazanmıştır. İngiltere ve $\mathrm{AB}$ arasında İngiltere'nin ayrılmasının ardından kurulacak ilişkiye hâkim olacak kuralları belirlenmek üzere taraflar arasında müzakereler yürütülmüştür. İngiltere'nin AB'den çıkış süreci resmi olarak Mart 2017'de başlamıştır. Sürecin başlamasının hemen ardından üye ülkelerden İspanya özelinde olmak üzere $\mathrm{AB}$ ile İngiltere arasında Cebelitarık'ın İngiltere'nin üyelikten ayrılması sonrasındaki statüsüne dair bir tartışma ve restleşme yaşanmıştır (Habertürk). İngilizler diplomasi oyununda her ne kadar oldukça başarılı olsalar da, müzakere tecrübesi oldukça fazla olan Avrupa Komisyonu da müzakereler sırasında $\mathrm{AB}$ 'nin çıkarlarını en iyi şekilde korumak için büyük bir çaba göstermiştir.

İngiltere, $A B$ 'nin bütünleşmesine dair şüpheleri yüksek olan tek $\mathrm{AB}$ üyesi değildir. Danimarka ve Avusturya gibi $\mathrm{AB}$ bütünleşmesinin ilerlemesi konusunda her zaman ihtiyatlı bir tutum içinde olan başka $\mathrm{AB}$ üyesi ülkeler de mevcuttur. Dolayısıyla İngiltere ile yapılan müzakereler ve ortaya çıkacak olan tablo, AB'den çıkış ihtimalini tartışan diğer $\mathrm{AB}$ üyesi ülkelerin bu yönde bir karara varıp varmamaları açısından belirleyici olacaktır. Yani İngiltere'nin üyelikten çıkış süreci, AB'nin gelecekteki üyelik yapısını köklü bir şekilde etkileme potansiyeli taşımaktadır. Ama İngiltere'nin AB üyeliğinden ayrılması, $\mathrm{AB}$ içindeki bütünleşme muhaliflerinin önemli ölçüde kan kaybetmesini beraberinde getirecektir. Diğer sorunları ile başa çıkmasını bilen bir AB'nin, bütünleşmeyi daha ileri noktalara taşımak üzere atılan adımlara içeride sürekli bir muhalif tutum içinde olan İngiltere'nin engellemeleriyle karşılaşmadan, eskisine göre daha başarılı bir bütünleşme haline gelme ihtimali de mevcuttur. Ancak değişen oranlarda olsa bile neredeyse tüm $\mathrm{AB}$ üyesi ülkelerde yükselişe geçen ve ülkelerindeki problemlerin temelinde $A B$ 'nin ya da $A B$ üyeliğinin var olduğu iddiasında bulunan aşırı sağ ve popülist eğilimler, bu ihtimalin ortaya çıkmasına en azından kısa vadede engel olacak gibi görünmektedir.

\subsection{Avrupa Birliği’nin Rusya ile Arasındaki Pürüzler}

AB'nin diş politikadaki güçsüzlüğünü son dönemde gözler önüne seren en önemli gelişmelerden biri, Rusya'nın AB ile daha ileri bir işbirliğine ulaşmak üzere adımlar atan Ukrayna'da karışıklıklar çıkarması ve bu ülkenin yönetimi altında bulunan Kırım'ı ilhak etmesine AB'nin verdiği tepki olmuştur. Özellikle doğalgaz konusunda Rusya'ya bağımlılığı yüksek $\mathrm{AB}$ üyesi ülkeler olmak üzere, neredeyse $\mathrm{AB}$ üyesi ülkelerin tamamı; Ukrayna nedeniyle Rusya ile yaşanan krizin diplomatik yollarla aşılması gerektiğinden yana bir tavır sergilemiştir. 
Ukrayna'nın toprak bütünlüğüne yönelik tehditlerinin ve faaliyetlerinin artması sonucunda Rusya'nın gerçek niyetine ilişkin güvensizliğin ortaya çıkmasıyla bu ülkeye karşı yaptırım uygulanması ihtimali gündeme geldiğinde ise üye ülkeler uzlaşıya varmakta bir hayli zorlanmıştır (Natorski ve Pornorska, 2017: 60).

Ukrayna krizi sonrasında Rusya ile yaşanan gerginlikle mücadele ederken üye devletler arasında yaşananlar, AB'nin enerji konusundaki yüksek dışa bağımlılığının güçlü bir dış politika aktörü haline gelebilmesi açısından ne denli kilit önemde olduğunu bir kere daha gözler önüne sermiştir. Rusya'nın olası yaptırımlara cevaben elini kuvvetli hale getirmek üzere büyük bir cesaretle oynadığı enerji kartı, bazı AB üyesi ülkeleri Rusya'ya uygulanması gündeme gelen yaptırımlar konusunda geri adım atmak zorunda bırakmıştır. Buna rağmen özellikle Kırım'ın Rusya tarafından işgal edilmesinin ardından, AB üyesi ülkeler üst düzey kararları alan bazı Rus vatandaşlarına, $A B$ 'ye seyahat yasağı getirme ve bazı Rus şirketlerinin faaliyetlerini durdurma yönünde alınan kararları ortaklaşa uygulayabilmişlerdir (Natorski ve Pornorska, 2017: 63).

\subsection{Avrupa Birliği Üyesi Ülkelerde Yükselişe Geçen Aşırı Sağ, Yabancı Düşmanı ve Avrupa Şüphecisi Eğilimler}

$\mathrm{AB}$ Antlaşmasının ikinci maddesinde $\mathrm{AB}$ 'nin temel değerlerinden biri olarak zikredilen dayanışma, krizlerle mücadele eden $\mathrm{AB}$ açısından kanayan bir yara halini almıştır. Krizler karşısından üye devletler çoğunlukla genel AB çıkarlarını düşünmekten ziyade kendi ulusal çıkarlarını öncelikli gören bir tutum içinde olmuştur. Üye devletler kendi ulusal çıkarlarından beslenen fikirlerinin $\mathrm{AB}$ çözümü hale gelmesini sağlamak üzere rekabete girmiştir. Almanya, $\mathrm{AB}$ içindeki yükselen gücünü krizlerle mücadele kapsamında alınan tedbirlerin kendi önceliklerine uygun şekillenmesi için sıklıkla kullanarak fırsatçı bir davranış göstermiştir. $\mathrm{Bu}$ dönemde güçlü bir işbirliği ve karşılıklı dayanışma $\mathrm{AB}$ üyesi ülkeler arasındaki ilişkilerin baskın boyutu haline gelememiş̧ir. Bu ortamda üye devletlerin iç siyasetinde milliyetçilik dozu yükselmiş ve radikal siyasi partilerin oylarında artışlar gözlenmiştir (Norkienė, 2017: 185, 186). Başka bir deyişle, AB şüphecisi olan ve bir zamanların modası geçmiş milliyetçiliğini yeniden körükleyen aşırı sağ partiler kolaylıkla Avrupa siyasetinde yeniden önemli aktörler haline gelmiştir.

Avrupa'da her zaman yabancı düşmanı eğilimler söz konusu olmuştur. Avrupa'da 2000 sonrası dönemde giderek artan ve sonu gelmeyen kriz ortamı da bu eğilimlerde önemli bir artışa neden olmuştur. Göçmen krizi de bu eğilimleri daha güçlü kılmıştır. Eskiden Avrupa toplumlarının küçük bir kısmında varlık bulan bu aşırı eğilimler, marjinal olmaktan çıkarak son yıllarda giderek ana akım eğilimler haline gelmiştir. AB üyesi ülkelerde aşırı săg, hatta ırkçı partiler iktidar 
ortağı haline gelirken merkez sağda yer alan partiler de siyaseten daha sağa kaymak zorunda kalmıştır (Erdenir, 2014: 96). Avrupa'da son dönemde açıkça ifade edilen İslam ya da Türk düşmanlığı artık bir kriz haline dönüşen yabancı düşmanlığının birer ifadesi niteliğindedir.

Krizler, mevcut siyasi sisteme muhalif olan aktörleri güçlü kılmaktadır. Kriz ortamında bu aktörlerin sisteme yönelik getirdiği eleştiriler daha inandırıcı bir hale gelirken, sistem taraftarı aktörlere olan destek önemli ölçüde azalmaktadır. Bu ortamda üye devletlerdeki iktidarların da kendilerini hedef alan muhalif söylemlerle mücadele etmek üzere sistemdeki sorunların sorumlusu olarak AB'yi işaret etme eğilimlerinde de bir artış meydana gelmektedir (Saurugger, 2016: 77, 79). Tüm dünyada AB tarafından savunulduğu iddia edilen demokratik değerler ve insan haklarıyla taban tabana tezat teşkil eden bu tür eğilimlerin gelecek dönemde AB'yi daha fazla zorlar hale gelmesi muhtemeldir.

\subsection{Ayrılıkçı Eğilimler}

Son dönemlerde $\mathrm{AB}$ gündeminde yer bulan kriz konularından biri de bazı üye devletlerde yükselişe geçen ayrilıkçı hareketlerdir. İspanya içinde yer alan Katalan bölgesinin düzenlenen referandumun ardından bağımsızlık ilan etme girişiminde bulunmasından sonra, bazı üye devletlerde var olan ayrılıkçı eğilimlere başka bir gözle bakılır olmuş ve konu giderek daha fazla kriz olarak nitelenir bir hal almıştır.

Gelecek dönemde İspanya örneğine benzer olarak İngiltere (İskoçya), Belçika (Flaman Bölgesi), İtalya (Kuzey İtalya ya da Venedik Bölgesi) ve Almanya (Silezya Bölgesi) gibi başka AB üyesi ülkelerde de ayrılıkçı eğilimlerin hız kazanması söz konusu olabilir. Bu nedenle de Katalonya'nın bağımsızlık yönündeki taleplerine yalnızca İspanya'ya özgü bir sorun olarak yaklaşılmamıştır. Zira önde gelen AB kurumları tarafından yapılan açıklamalar da AB'nin bu durumdan hoşnutsuzluğunu gösterir niteliktedir. Örneğin, Avrupa Komisyonu Başkanı Juncker abartılı bir tutum benimseyerek 95 üyeli bir AB'yi görmekten memnuniyet duymayacağını ifade ederken; Avrupa Konseyi Başkanı Donald Tusk, İspanya'nın tek muhatapları olduğunu ifade etmiştir (BBC News). Avrupa Parlamentosu Başkanı Antonio Tajani de kimsenin Katalonya'nın bağımsızlığını tanımayacağı çıkışında bulunmuştur. Ayrıca konunun, İspanya'nın iç meselesi olduğunu belirterek AB'nin taraflar arasında arabuluculuk yapmasının mümkün olmadığına işaret etmiştir (US News). Benzer şekilde $\mathrm{AB}$ üyesi ülkelerin devlet ve hükümet başkanları da bu krizde Madrid yönetiminden yana bir tavır içinde olmuştur. 


\section{Sonuç}

$\mathrm{AB}$ 'de krizler sürpriz bir şekilde nadiren yaşanan gelişmelerden ziyade $\mathrm{AB}$ siyasetinde her zaman yaşanan olağan gelişmeler niteliğindedir (Lawrence, 2013: 194). Zira Topluluk ya da Birlik kuruluşundan itibaren sürekli olarak krizlerle mücadele etmek zorunda kalmış ve günümüze kadar karşı karşıya olduğu krizleri ya bir şekilde ortadan kaldırmayı başarmış ya da bu krizlerle mücadele ederek yoluna devam etmeyi bilmiştir. Geçmişte yaşanan krizler AB bütünleşmesi açısından aynı zamanda bir öğrenme deneyimi niteliğinde olmuştur. Bu sayede yeni krizler ilk etapta şaşkınlık, panik ve belirsizlik yaratsa bile sonrasında $\mathrm{AB}$, krizin tanımlanmasının ardından, geçmişte öğrenilen çözüm mekanizmaları ve modellerine işlerlik kazandırmıştır (Kamkhaji ve Radaelli, 2017: 729). Çünkü $A B$, geçmişte karşılaştı̆̆ krizlerden güçlü şekilde çıkmanın bir yolunu er ya da geç bulmuştur. Yani $\mathrm{AB}$, krizlere rağmen dünyadaki en başarılı bölgesel bütünleşme örneği haline gelmeyi başarmıştır.

2000 sonrası dönemde $\mathrm{AB}$ birbiri ardına ve eş zamanlı olarak kriz niteliğindeki güçlü meydan okumalarla karşı karşıya gelmiştir. AB'nin bu meydan okumalara dayanıp dayanamayacağı ya da bu meydan okumalar sonrasında nasıl bir $\mathrm{AB}$ ile karşı karşıya olunacağı hâlihazırda belirsizdir. Farklı gerçeklere odaklanarak AB'nin gündeminde olan krizleri farklı şekilde yorumlamak ve Birliğin geleceğine dair farklı gelecek senaryoları üretmek mümkündür (Lawrence, 2013: 195). Dolayısıyla hiçkimse AB'ye hâkim olan kriz ortamını inkâr etmezken, birçok kişi AB'nin içinden geçtiği kriz ortamını farklı şekillerde yorumlayarak $\mathrm{AB}$ bütünleşmesinin geleceğine ilişkin farklı senaryoları gündeme getirmektedir. $\mathrm{Bu}$ ortamda $\mathrm{AB}$ 'nin dağılacağını bile savunanlar olmuştur. Buna karşın, AB bütünleşmesi gelecekte de büyük ihtimalle bir şekilde varlığını korumaya devam edecek gibi görünmektedir. Zira üye ülkelerin $\mathrm{AB}$ 'den elde ettikleri kazanımlar, halen $\mathrm{AB}$ 'yi koruma konusunda ısrarcı olmalarına imkân tanımaktadır. Ancak, mevcut krizlerin ardından AB'nin geçmişte olduğundan daha farklı bir görünümde olması muhtemeldir.

$\mathrm{AB}$ geçmişte olduğu gibi bundan sonraki dönemlerde de yeni krizlerle de yüzleşmek zorunda kalarak, yaşanan krizlerin $\mathrm{AB}$ sistemine büyük yaralar açmaması için enerji harcayacaktır. $\mathrm{Ama} A B$, krizlerle birlikte görünür hale gelen zaaflarını ortadan kaldıramazsa, $\mathrm{AB}$ açısından gelecek dönemde ortaya çıkacak olan krizlerle mücadele etmek daha zorlu bir deneyim haline gelecektir. 


\section{Kaynakça}

--- (2014), Europe Recast: A History of European Union (Boudler: Lynne Reiner Publishers).

Bauer, Michael W. ve Stefan Becker (2014), "The Unexpected Winner of the Crisis: The European Commussion's Strengthed Role in Economic Governance", Journal of European Integration, 36 (3): 213-229.

BBC New, http://www.bbc.com/news/world-europe-41783957, (23.11.2017).

Begg, lain (1999), "Reshaping the EU Budget: Yet Another Missed Opportunity?", ECSA Conference Paper.

De Grauwe, Paul (2016), “What Future for the EU After Brexit?”, Intereconomics: 259-251.

Desmond, Dinan (2008), Avrupa Birliği Tarihi (İstanbul: Kitap Yayınevi) (Çev. Hale Akay).

Erdenir, Burak (2014), “Avrupa Birliği’nin Geleceği: Türkiye-AB İlișkileri”, Belgin Akçay (Der.), Türkiye$A B$ Iliş̧ileri: Yeni Gündem, (Ankara: Seçkin Yayıncılık): 94-108.

Erdoğan, Seven ve Hatice Yazgan (2017), "Avro Krizi, Siyasi Etkileri ve AB Genişlemesine Yansımaları”, Ankara Üniversitesi SBE Avrupa Birliği ve Uluslararası Ekonomik Illişkiler ABD 25. Yıl Armağan Kitabı, (Ankara: Ankara Üniversitesi Basımevi): 195-216.

Fahir Armaoğlu (2016), 20. Yüzyıl Siyasi Tarihi 1914-1995, (İstanbul: Timaş Yayınları), 21. Baskı.

Habertürk (2017), http://www.haberturk.com/dunya/haber/1447863-avrupa-birligi-ile-ingilterearasinda-cebelitarik-gerilimi, (20.04.2017).

Hooghe, Liesbeth ve Gary Marks (2006), "Europe's Blues: Theoretical Soul-Searching after the Rejection of the European Constitution", PSOnline: 247-250.

Issawi, Charles (1978-79), "The 1973 Oil Crisis and After", Journal of Post Keynesian Economics, 1 (2): 3-26.

Joffe, Josef (1981), "European-American Relations: The Enduring Crisis", Foreign Affairs, 59 (4): 835-851.

Kamkhaji, Jonathan C. ve Claudio M. Radaelli (2017), "Crisis, Learning and Policy Change in the European Union", Journal of European Public Policy, 24 (5): 714-734.

Koeck, H. Franz (2017), "The Present Crisis of the European Union and Its Causes", The International Conference of European Union's History, Culture and Citizenship, Romanya-Pitesti: 22-38.

Kroll, Daniela Annette ve Dirk Leuffen (2016), "Ties that Bind, Can Also Strangle: The Brexit Threat and The Hardships of Reforming the EU", Journal of European Public, 23 (9): 1311-1320.

Kux, Stephan ve Ulf Sverdrup (2000), "Fuzzy Borders and Adaptative Outsiders: Norway, Switzerland and the EU", Journal of European Integration, 22 (3): 237-270.

Lawrence, Jessica C. (2013), "The EU in Crisis: Crisis Discourse as a Technique of Government", Netherlands Yearbook of International Law, 44: 187-202.

Ludlow, Piers (2013), "Hard-won But Vital: EU Enlargement in Historical Perspective”, LSE Research Online: $12-18$

McCormick, John (2014), Avrupa Birliği'ni Anlamak, (Ankara: BigBang Yayınları) (Çev.: Yusuf Şahin ve Hasan Hüseyin Şahin).

Monnet, Jean (1978), Memoirs, New York: Double Day \& Company) (Çev.: Richard Mayne).

Natorski, Michal ve Karolina Pomorska (2017), "Trust and Decision-Making in Times of Crisis: The EU's Response to the Events in Ukraine", Journal of Common Market Studies, 55 (1): 54 70. 
Norkienè, R. Mienkkowska (2017), "Crisis of Solidarity in the European Union- No More Dreams of Europe's Competitive Advantage", Economics World, 5 (3): 183-194.

Öniş, Ziya, (2001) "Greek-Turkish Relations and the European Union: A Critical Perspective", Mediterranean Politics, 6 (3): 31-45.

Özdemir, Haluk (2012), Avrupa Mantığı: Avrupa Bütünleşmesinin Teori ve Dinamikleri, (İstanbul: Boğaziçi Üniversitesi Yayınevi).

Saurugger, Sabine (2016), "Sociological Approaches to the European Union in Times of Turmoil", Journal of Common Market Studies, 54 (1): 70-86.

Schimmelfennig, Frank (2014), "European Integration in the Euro Crisis: The Limits of Postfunctionalism", Journal of European Integration, 36 (3): 321-337.

Smith, Karen E. (2003), European Union Foreign Policy in A Changing World, (Cambridge: Polity Press).

Tekin, Beyza C.. (2014), "Rethinking the Post-National EU in Times of Austerity and Crisis", Mediterranean Politics, 19 (1): 21-39.

Tosun, Jale, Anne Wetzel and Galina Zapryanova (2014), "The EU in Crisis: Advancing the Debate", Journal of European Integration, 36 (3): 195-211.

US News, https://www.usnews.com/news/world/articles/2017-10-28/the-latest-anti-independenceactivists-protest-in-madrid, (12.11.2017).

Wirth, Tara (2016), “The European Union's Framing of the European Refugee Crisis”, Elon Journal of Undergraduate Research in Communications, 7 (2): 45-56. 